ACTA THERIOLOGICA

Vol. 24, 26: 363-377, 1979

\title{
The Ecology of Glaucomys volans (Linnaeus, 1758) in Virginia ${ }^{1}$
}

\author{
Daniel E. SONENSHINE, David M. LAUER, Thomas C. WALKER \\ \& Bennett L. ELISBERG
}

Sonenshine D. E., Lauer D. M., Walker T. C. \& Elisberg B. L., 1979: The ecology of Glaucomys volans (L innae us, 1758) in Virginia. Acta theriol., 24, 26: 363-377 [With 4 Tables \& 5 Figs.]

The ecology of the southern flying squirrel, Glaucomys volans (L in$\mathrm{n}$ a e u s, 1758) was studied in 2 areas of central Virginia, using artificial tree shelter traps and baited live trapping. Within one year after their installation, $46.9 \%$ of the artificial shelters were used for nesting sites, $26.6 \%$ as feeding stations, and $17.2 \%$ as defecatoria; only $9.4 \%$ were without evidence of use. The animals utilized several shelters for nesting in addition to others used for food storage and defecatoria. In habitat selection, availability of bodies of fresh water was important, but the slope of the terrain was not significant. Foraging (average range $126.8 \mathrm{~m}$ \pm 14.8 S.E.) was not significantly related to distance from aquatic habitat. Adult males foraged substantially farther than sexually inactive females or juveniles. Most females $(94.2 \%)$ became pregnant within $6-8$ months after birth. Birth of young occurred in early spring, March and April. and in late summer, from August to early October. Removal rate of young squirrels from the population by mortality was $50 \%$ within 5.5 months and $67 \%$ in 7 months. Population density, estimated by the Petersen index and regression analysis of recapture frequency, varied at different seasons from 4.5 to 10.1 flying squirrels/ha at one of the localities, and from 6.2 to 13.8 /ha at the other.

[Dept. Biol. Sci., Old Dominion Univ., Norfolk, Virginia 23508 (DES, DML, TCW); Div. Pathol., Bureau of Biologics, Food and Drug Administration, U. S. Public Health Service, DHEW, Bethesda, Maryland 20014 (BLE)].

\section{INTRODUCTION}

The southern flying squirrel ranges from Ontario and Minnesota (S tormer \& Sloan, 1976) southward throughout the eastern and central United States to central Mexico. Despite its wide range and abundance, relatively little is known of the ecology of this highly secretive, nocturnal animal. Perhaps the most extensive investigations

1 Supported in part by a contract DADA-17-72-C2062 with the U.S. Army Medical Research and Development Command, Office of the Surgeon General, Department of the Army, Washington, D. C. 20314, and, in part, by a contract FDA 223-73-1188 with the Bureau of Biologics, Food and Drug Administration, U.S. Public Health Service, Department of Health, Education and Welfare, Bethesda, Maryland 20014. 
were those by Mu ul (1968, 1969, 1970, 1974), who worked with populations in Michigan and Massachusetts, near the northern limit of the range. Other ecologic studies were done by J o r d a n (1948), S o 11 be r g e r (1943), M oor e (1961), W e ig l (1974), Go ertz et al. (1975) and $\mathrm{Madden}(1974,1976)$. Flying squirrel activity rhythms were studied by D e C o u r s e y $(1960,1961,1972$, and 1973) under laboratory conditions.

Recently, B o z e ma n et al. (1975) described a reservoir of epidemic typhus (Rickettsia prowazeki in several populations of G. volans). In view of the association of the flying squirrel with this important disease organism, the need for detailed information on the ecology of the flying squirrel is increased. Research on the epizootiology of this zoonosis provided an opportunity to study the ecology of the flying squirrel in a limited area, involving capture and examination of almost 400 individuals, during all seasons of a consecutive 4-year period. The results provide new findings on population regulation and habitat utilization of the flying squirrel in central Virginia.

\section{MATERIALS AND METHODS}

Two study areas were chosen. The Ashland Study Area (Fig. 1) in Hanover County comprised 12.8 ha of mature hardwood forest and was used from 1972 to 1976. The Lorne Study Area (Fig. 2) in Caroline County, approximately 15 miles distant, included 7.8 ha and was used from June, 1974 through April, 1975. Both areas included relatively flat uplands sloping to streams, a lake or a pond. Slopes ranged from $3^{\circ}$ to $24^{\circ}$ per $100 \mathrm{~m}$ at different sections of the 2 areas, excluding occasional steep banks beside the streams. Vegetation at the 2 areas was primarily subclimax deciduous forest, with a small tract of pine ( 0.9 ha) at the Lorne area; neither area had been recently lumbered. Dominant tree species on the uplands included oaks, hickory and beech; on the lower slopes and in the swamps, additional species found included ironwood, birch and gum.

The areas were sampled by two capture methods, namely 1) artificial shelter traps, and 2) baited live traps. Artificial shelter traps (S o n e n shine et al., 1973) were installed on trees at a height of from 3.7 to $4.3 \mathrm{~m}$ in a grid system at intervals of $32 \mathrm{~m}$, providing a trap density of 9.9/ha (128 traps at Ashland and 77 at Lorne). Squirrels in the shelter traps were captured by sealing the aperture, opening the door and removing them separately through the screen guard with the gloved hand. The artificial shelter traps were monitored at regular intervals troughout the study period. Baited live trapping was done with Sherman traps $(7.6 \times 7.6 \times 25.4 \mathrm{~cm})$ installed on trees at the same sites as the artificial tree shelters. The traps were oriented vertically with the doors facing the ground and positioned at a height of $2.4 \mathrm{~m}$ elevation, the highest elevation accessible without tree climbing aids; further increase in height did not improve trap success. Ground trapping was ineffective and was not used. The live traps were baited with peanut butter and set at approximately weekly intervals during the warm months of the year, June through September. Baited live trapping (on trees) was not done during the colder months to avoid loss of animals from cold stress. 
All animals captured were brought to the field laboratory for processing. Ear tags (Salt Lake City Stamp Company, Salt Lake City, Utah) were used to tag each individual. Weight, sex, estimated age (according to S ol be r g e r, 1943) and reproductive condition were recorded at each capture. In addition, blood samples ca. $0.2-0.3 \mathrm{ml}$ were taken by orbital bleeding ( $\mathrm{R}$ ile y, 1960) at no less than two week intervals; nursing juveniles, pregnant or nursing females and animals showing signs of stress were not bled.

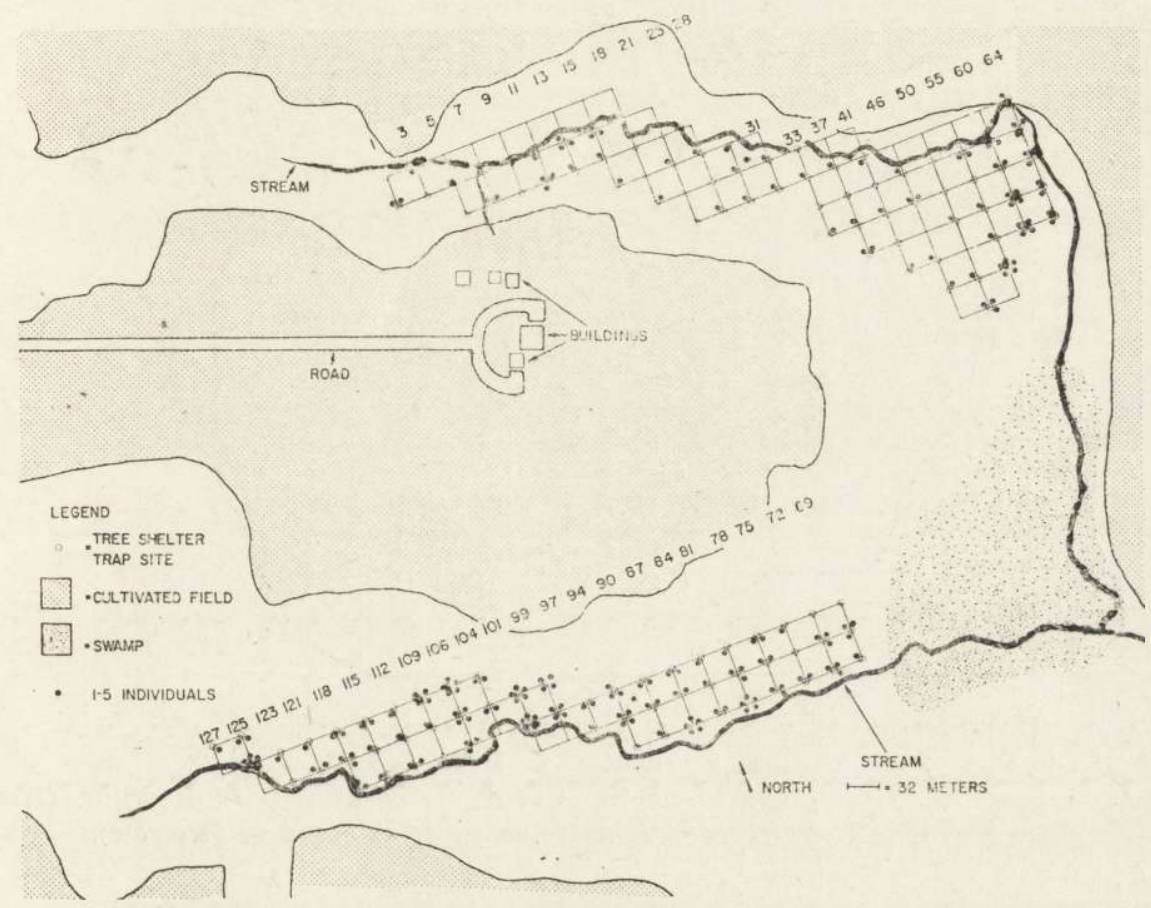

Fig. 1. Map of the trapping grid at the Ashland study area, Ashland, Virginia Black circles represent flying squirrel captures (5/circle).

Estimates of population size were made using the Petersen index (D a vis, 1963) and the regression analysis of recapture frequency (E d wards \& Eberhardt, 1967). We modified Edwards and Eberhardt's technique by comparing the $\log$ of the number of individuals in each capture class (dependent variable) with individual capture frequency (independent variable). No estimates were prepared for periods when pregnancy, parturition and rearing of young might bias the results. Corrections for mortality were made, using the results of a survival study.

\section{RESULTS}

\subsection{Shelter Trap Utilization}

Flying squirrels commenced using the artificial shelter traps within a few days after installation and continued using them extensively from 
October through May in each year, but only sporadically during the intervening warmer months. Over the 4-year study period, 1, 111 captures were made in the 128 artificial tree shelters at Ashland, 280 at Lorne. Flying squirrel use of the shelters at the different available sites

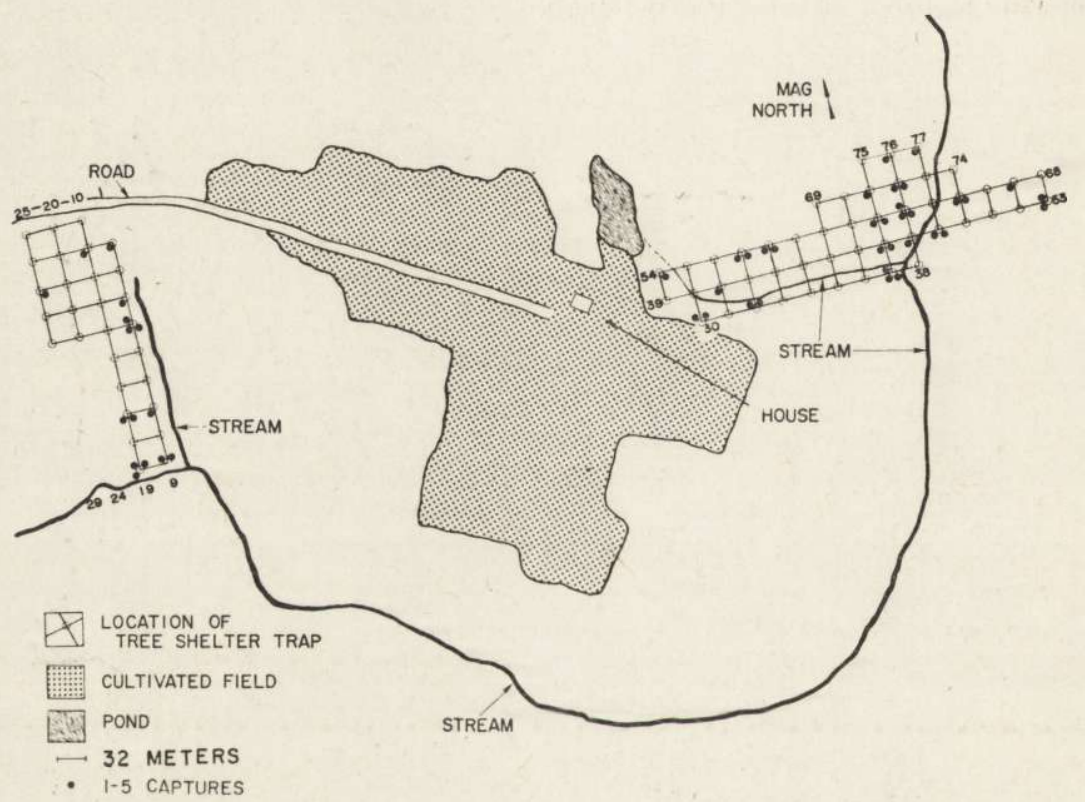

Fig. 2. Map of the trapping grid at the Lorne study area near Bowling Green, Virginia. Black circles represent flying squirrel captures (5/circle).

Table 1

Frequency of capture of flying squirrels in artificial tree shelter traps at the Ashland study area, June 1972 - April 1976.

Total No. Captures in the same shelter No. Shelter Traps

$\begin{array}{rr}0 & 27 \\ 1-5 & 42 \\ 6-10 & 20 \\ 11-15 & 14 \\ 16-20 & 8 \\ 21-25 & 10 \\ 26-30 & 6 \\ >30 & 1\end{array}$

was selective. During the 4-year study period at Ashland, no animals were caught in $21.1 \%$ of the shelters and only $1-5$ individuals were found in $35.9 \%$ other shelters. The remainder were heavily used (Table 
1). Maximum usage of a single box was indicated by 36 captures, representing 24 individuals.

A distinct seasonal trend in shelter use was noted, with aggregation more frequent in winter. The number of flying squirrels simultaneously caught in a single box varied from 1 to 13 . Monthly averages of aggregation size were minimal in November (2.3), maximal in January (3.5) at Ashland. A similar pattern was found over the 8-month study period at Lorne. Aggregation size declined in February prior to the spring peak of parturition. The shelter traps were rarely used during the summer months.

The 4-year observation period at Ashland revealed multipurpose use of the tree shelter system. Flying squirrel use could be distinguished from that of other species by their characteristic nests, fecal droppings, and their method of opening acorns or nuts. Approximately $90 \%$ of the shelters showed evidence of some type of use by flying squirrels within 1 year after their installation. Almost half of the tree shelters had nests in them. The large number of nests, several times the number of aggregations, suggested that the flying squirrels used more than 1 nest during the cold weather period. The winter nests were made almost entirely of cedar bark, and ranged in weight from 24.8 to 171.7 grams (average 62.9 grams); they were used either for aggregations or for a single female and her offspring. Nests were also constructed in summer (June through August) of fresh leaves and cedar bark and were lighter in weight, from 5.1 to 87.5 grams (average 30.9 grams). Other shelters were used by the flying squirrels as food caches $(26.6 \%)$ or as defecatoria $(17.2 \%)$.

\subsection{Association with Aquatic Habitat and Terrain Characteristies}

Flying squirrels tended to nest in shelters near bodies of water more frequently than elsewhere (Table 2). The distribution of captures in the tree shelters indicated a highly significant deviation from random, with a strong bias against those shelters farthest from aquatic habitat $\left(\chi^{2}=43.16,3\right.$ d.f., $p<0.001$ at Ashland; $\chi^{2}=60.58,3$ d.f., $p<0.001$ at Lorne). However, the distribution of flying squirrel captures in baited live traps was not significantly related to distance from aquatic habitat $\left(\chi^{2}=0.30,3\right.$ d.f., $p<0.90$, not significant). Presumably, the foraging needs of these animals are not as affected as their sheltering requirements by the availability of aquatic habitat. Slope of the terrain was also considered; several different categories of terrain slope were present, ranging from $6^{\circ}$ or less to as much as $24^{\circ}$. However, no clearly defined relationship was found in this case; more captures than expected were 
found in areas with the least slope and with the greatest slope, while: fewer than expected were found in areas with intermediate slope. The influence of terrain slope, therefore, is not regarded as an important factor influencing flying squirrel distribution.

\section{Table 2}

Summary of flying squirrel occurrence in relation to aquatic habitat at two study areas in Virginia.

\begin{tabular}{|c|c|c|c|c|c|c|c|c|}
\hline \multirow[b]{2}{*}{ Distance, } & \multirow[b]{2}{*}{$\mathrm{m}$} & \multicolumn{4}{|c|}{ Ashland } & \multicolumn{3}{|c|}{ Lorne } \\
\hline & & $\begin{array}{c}\text { No. } \\
\text { locations }\end{array}$ & $\begin{array}{l}\% \text { of } \\
\text { total }\end{array}$ & $\begin{array}{l}\text { No. anin } \\
\text { tree } \\
\text { shelters }\end{array}$ & $\begin{array}{l}\text { als in: } \\
\text { live } \\
\text { traps }\end{array}$ & $\begin{array}{c}\text { No. } \\
\text { locations }\end{array}$ & $\begin{array}{l}\% \text { of } \\
\text { total }\end{array}$ & $\begin{array}{l}\text { No. animals } \\
\text { in tree } \\
\text { shelters }\end{array}$ \\
\hline \multirow{5}{*}{$\begin{array}{l}>32 \\
>64 \\
>96\end{array}$} & $<32$ & 56 & 43.8 & 492 & 147 & 36 & 46.7 & 151 \\
\hline & $<64$ & 42 & 32.8 & 375 & 104 & 23 & 29.9 & 115 \\
\hline & $<96$ & 24 & 18.8 & 111 & 71 & 11 & 14.3 & 7 \\
\hline & $<128$ & 6 & 4.7 & 50 & 15 & 7 & 9.1 & 7 \\
\hline & & 128 & - & 1028 & 337 & 77 & - & 280 \\
\hline
\end{tabular}

\subsection{Foraging activity}

Foraging range of individuals was determined by comparing consecutive captures in baited live traps. The mean range was $126.8 \mathrm{~m} \pm$ $14.8 \mathrm{~m}(\mathrm{~N}=23)$. The analysis was repeated using the individual's last known nesting site as the point of origin between successive captures in the baited traps. The new mean range, $158.1 \mathrm{~m} \pm 16.7 \mathrm{~m}(\mathrm{~N}=26)$, was not significantly different from the preceding estimate ( $t=1.37,66$ d.f.). Great variation in individual foraging ranges was observed. A total of $46.5 \%$ of all instances involved a foraging range of $92 \mathrm{~m} ; 2$ animals traveled $566 \mathrm{~m}$ and $800 \mathrm{~m}$, respectively, in a single night. Calculated ranges of 16 flying squirrels captured in baited live traps 5 or more times are illustrated in Fig. 3. Adult males had a mean range radius of 157.8 $\pm 39.2 \mathrm{~m}(\mathrm{~N}=5)$, non-reproductive females, $103.1 \pm 11.4 \mathrm{~m},(\mathrm{~N}=5)$ and juveniles only $102.8 \pm 19.3(\mathrm{~N}=5)$; the one lactating female had a range radius of $76.8 \mathrm{~m}$.

\subsection{Reproduction}

Two major peaks in reproduction occurred, one in the late summer and early fall, the second in the spring. This is summarized in Table 3, showing the rise in percent adult males with enlarged scrotal testes and percent of estrous or pregnant females. The data suggests that most males reached reproductive condition in advance of females. Some of this lag by females represents the 40-day gestation period, but the 
actual anticipation in males exceeded 40 days. Reproduction peaks art confirmed by the April and September peaks in lactaing females at Ashland, where the largest sample was observed. Weight changes of

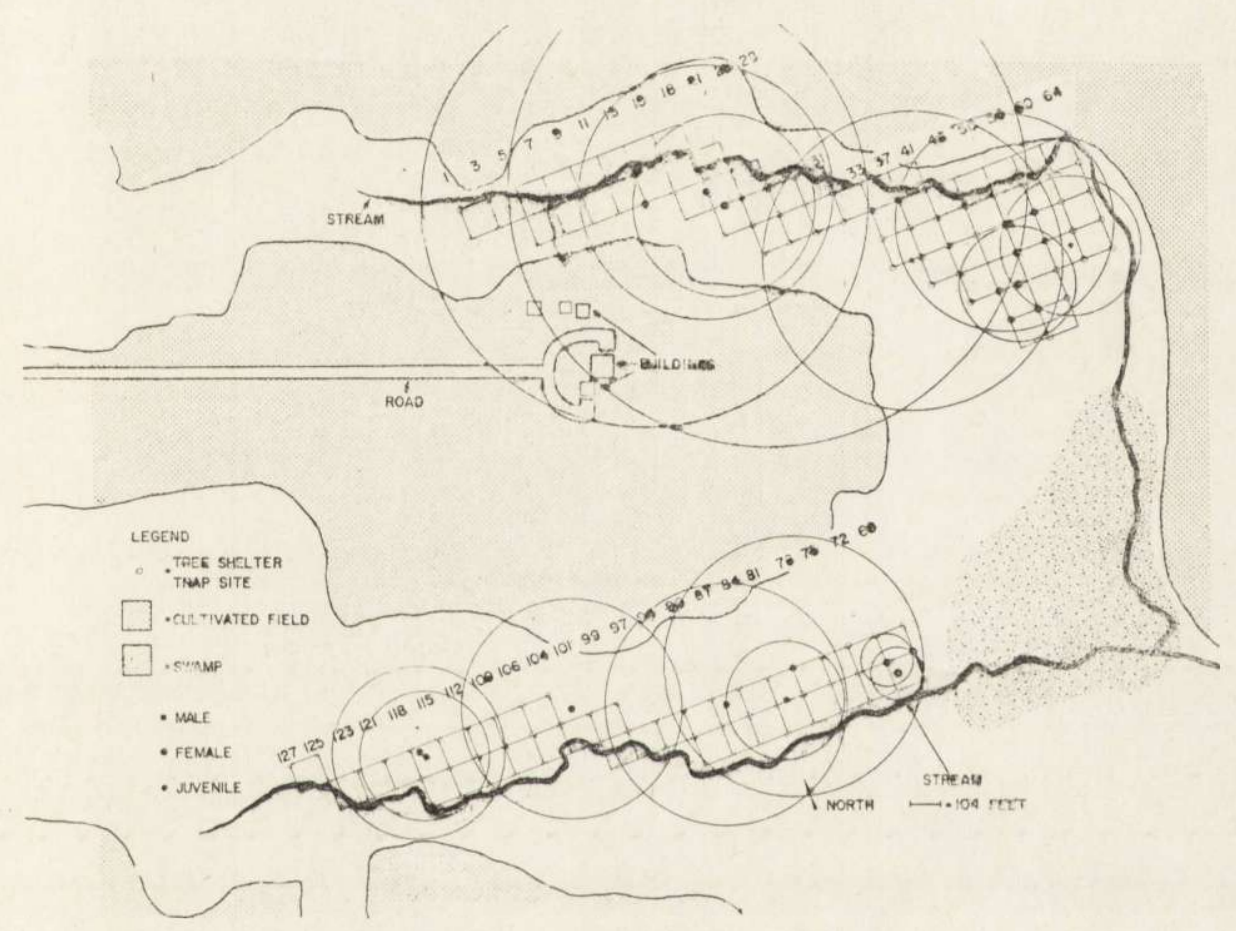

Fig. 3. Range of selected individual flying squirrels at the Ashland study area during the spring-summer trapping period as determined by the distance between successive recaptures.

adult flying squirrels also appeared to be correlated with the reproductive cycles (Fig. 4). Two sharp increases in female weight occurred at the time of the two breeding periods, April and August. The precipitous declines observed following these peaks probably reflects weight loss following parturition. In contrast, male body weight declined during periods of sexual activity, gradually during the winter months JanuaryMarch, precipitously during the summer period June-August.

The periods of reproduction are also evidenced by the discovery of sucklings as early as March and October and the frequency of occurrence of juveniles from March to August and October to January. Development of young was studied in the field and in a laboratory colony as a means of aging the animals. Flying squirrels acquired a fine coat of fur ap-- 


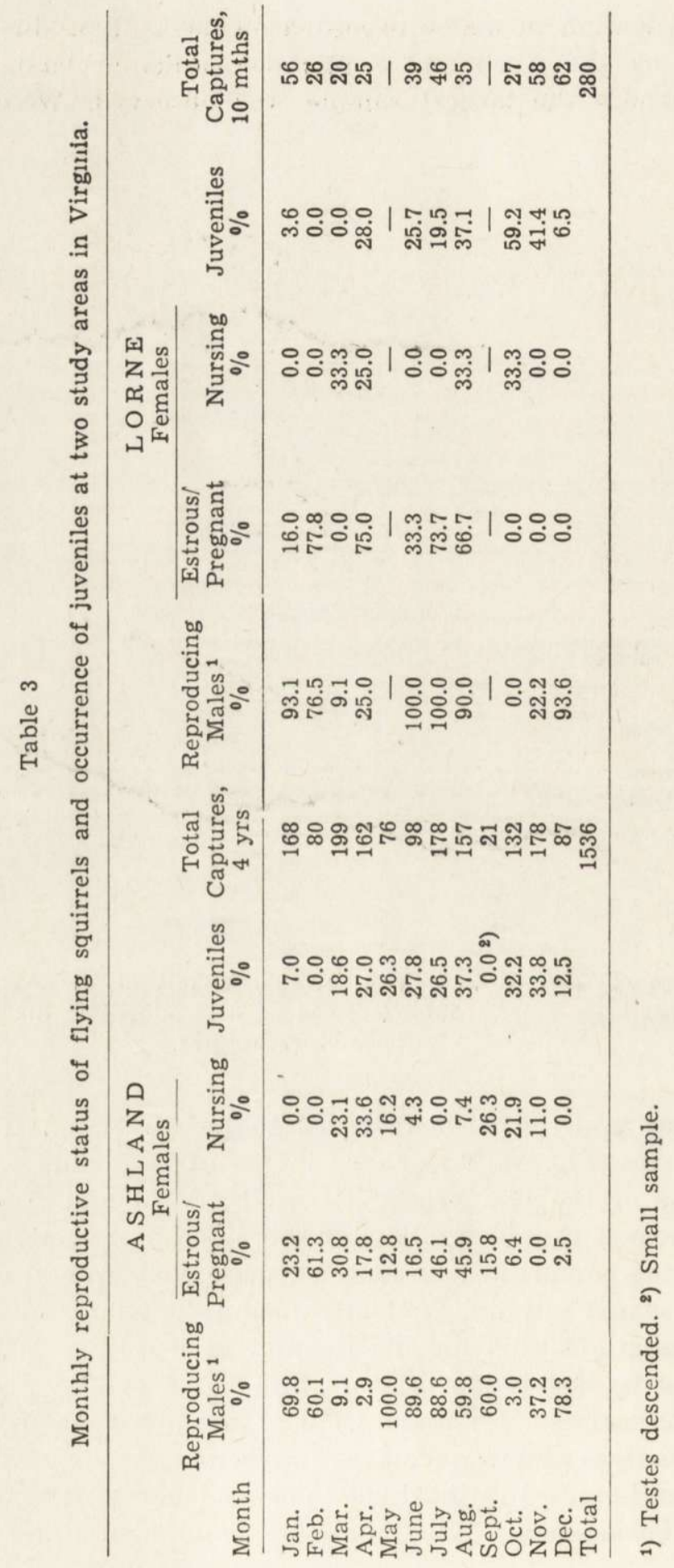


proximately $2^{1 / 2}$ weeks after birth; the eyes were opened fully at the middle of the fourth week. Weight gains of laboratory reared young increased approximately logarithmically during an 11-week period and resembled the growth pattern described by S oll ber ger (1943). In nature, nursing terminated after approximately 44 days. Juveniles began foraging and appearing in baited traps 60 to 80 days after birth. Weaned juveniles were recognized as individuals weighing less than approximately 60 grams, with a drab pelage. Adult features were acquired after

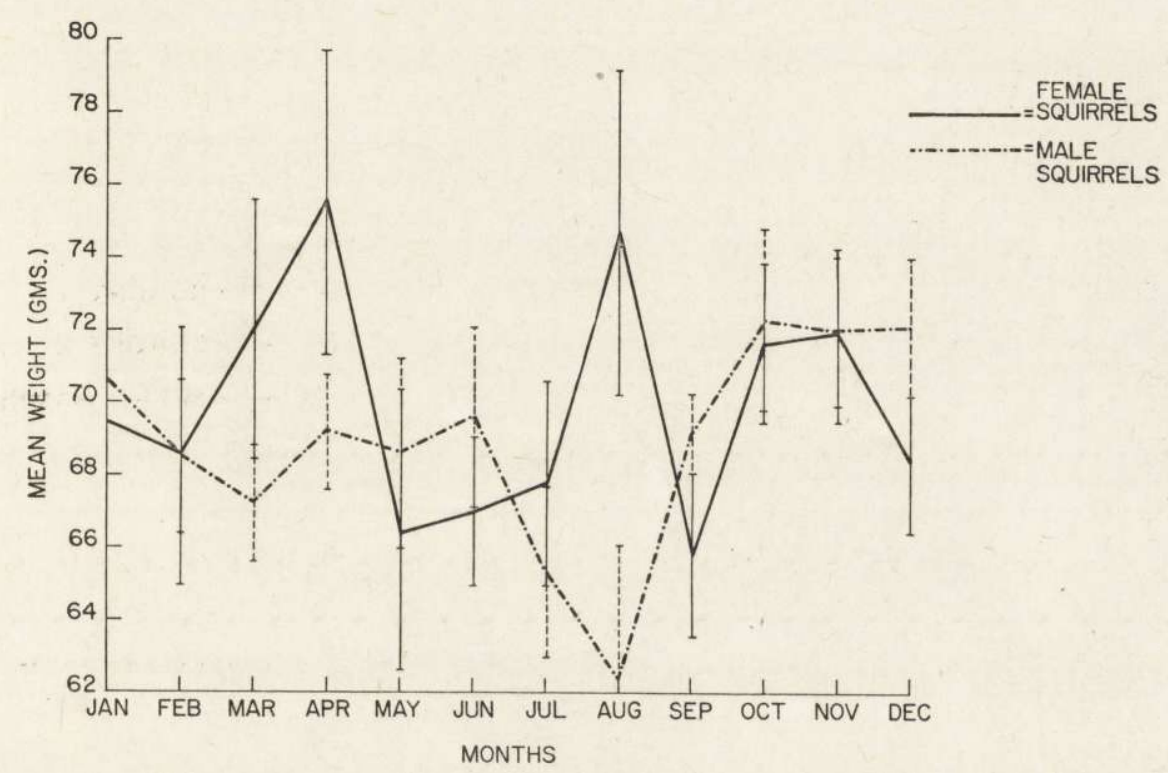

Fig. 4. Mean monthly weights of wild flying squirrels, Glaucomys volans, in a natural area near Ashland, Virginia. Vertical bars represent \pm 2 S.E.

approximately 4 months. Young flying squirrels tended to remain together in family groups, even after weaning, and usually with the mother.

Reproduction may be expected to occur in female flying squirrels during their first year. Data was accumulated for 27 females of known history, or which could be traced for extended periods. Most females $(94.2 \%)$ became pregnant within $6-8$ months after birth, at the next breeding season following their birth. The remainder became pregnant in the next breeding season 12-15 months after birth. Eight of these females were observed to become pregnant again, 5 within 6 months post-partum, the others within 12 months post-partum. One individuai became pregnant again in the following year, but aborted. The oldest. 
female to bear young was 3 years and 8 months old when it was found with a litter of 4 .

\subsection{Mortality}

Disappearance of individuals from the populations was believed to be due almost entirely to mortality, since the relatively isolated nature of the woodlots studied minimized emigration. At Ashland, tree shelter traps were deployed in nearby woodlots to intercept emigrating resident

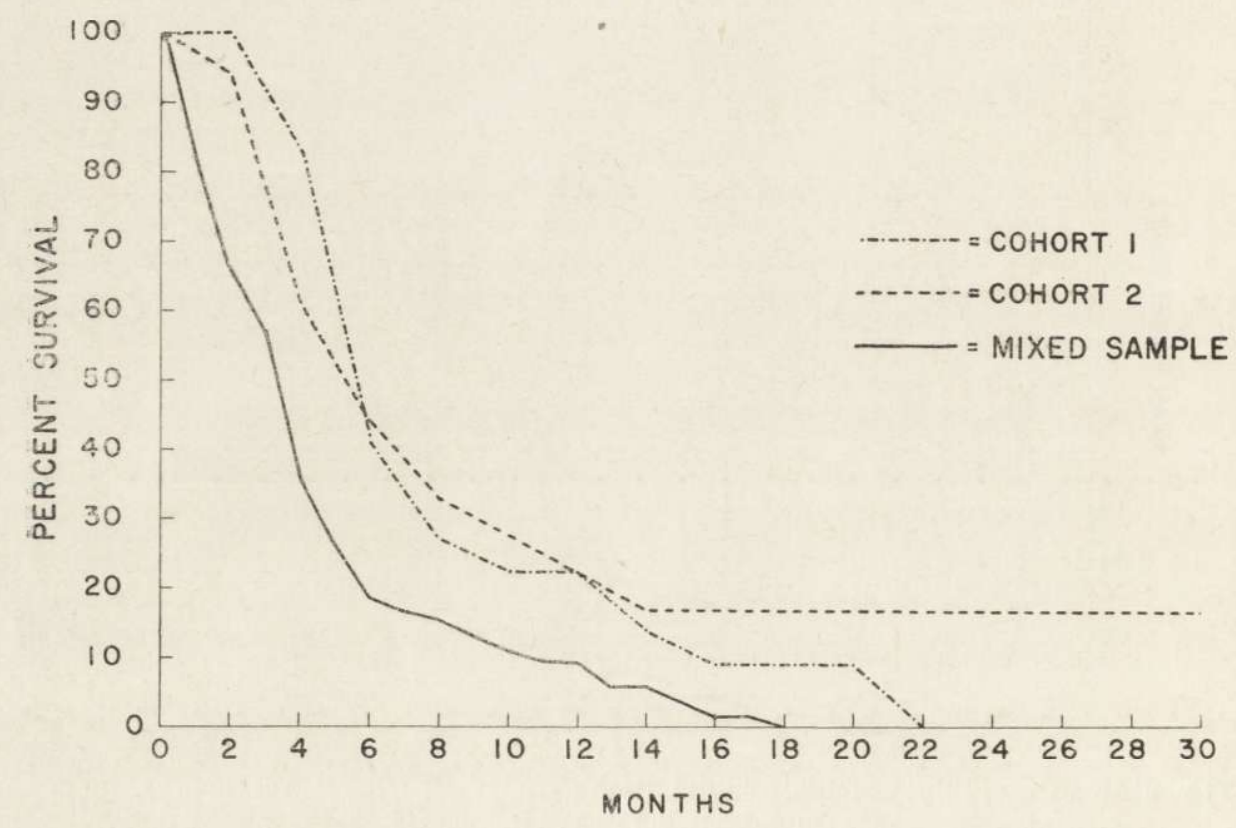

Fig. 5 .Survival curves for flying squirrels at the Ashland Study Area.

Cohort $1=22$ individuals born in the spring of 1973 ; Cohort $2=18$ individuals born in the fall of 1973; Mixed Sample $=53$ individuals of unknown age, captured for the first time in May or June of 1973, and monitored thereafter.

individuals; no captures or visitations were observed. Mortality was estimated by determining recapture rates over 2 years for specific population cohorts, namely, a spring born juvenile cohort and a fall born juvenile cohort. Finally, a mixed group of all ages, but captured at a specific time, was analyzed (Fig. 5). Disappearance of individuals in the juvenile cohorts during the first 2 months after they commenced foraging was negligible. More than half of the spring-born squirrels 
disappeared from the population within $5^{1 / 2}$ months, and two-thirds within 7 months. For the fall born squirrels, the same rate of disappearance values occurred within 5 and 8 months. The mixed population sample exhibited a more rapid rate of disappearance of individuals, with $50 \%$ absent after only $3^{1 / 2}$ months and $67 \%$ absent by 4 month after their first capture.

\subsection{Population Size}

The results of the two different methods of analysis suggest that population size at both study areas was lowest during the summer period,

Table 4

Summary of estimates and census values of the population of the southern flying squirrel, Glaucomys volans at the 2 Virginia study areas.

\begin{tabular}{ccccc}
\hline $\begin{array}{c}\text { Seasonal } \\
\text { Period }\end{array}$ Census & $\begin{array}{c}\text { Petersen index } \\
N \pm 2 \text { S.E. } \\
\text { (Dates) }\end{array}$ & $\begin{array}{c}\text { Regression of recapture frequencies } \\
\mathrm{N} \text { Conf. Limits } \mathrm{R}^{2}\end{array}$ & $\begin{array}{l}\text { Range of } \\
\text { (dates) } \\
\text { both est. } \\
\text { (avg/ha) }\end{array}$ \\
\hline
\end{tabular}

\begin{tabular}{|c|c|c|c|c|c|c|}
\hline $\begin{array}{l}\text { A. Ashlan } \\
\text { Summer, } \\
1972 \text {, }\end{array}$ & tudy & $\begin{array}{c}\text { area }(12.8 \text { ha) } \\
85 \pm 18 \\
(19-26 \text { June })\end{array}$ & 85 & $\begin{array}{l}83-87 \\
{[P<0.005]}\end{array}$ & $\begin{array}{l}0.99 \\
\text { (19 June }-21 \text { Aug.) }\end{array}$ & 6.7 \\
\hline $\begin{array}{l}\text { Fall, } \\
1972\end{array}$ & 55 & $\begin{array}{r}71.5 \pm 17.0 \\
(16-31 \text { Oct.) }\end{array}$ & 93 & $\begin{array}{l}91-95 \\
{[P<0.005]}\end{array}$ & $\begin{array}{l}0.91 \\
(31 \text { Oct. }-31 \text { Dec.) }\end{array}$ & $5.7-7.4$ \\
\hline $\begin{array}{l}\text { Spring- } \\
\text { Summer, } \\
1973\end{array}$ & 56 & $\begin{array}{l}56 \pm 22 \\
\text { (5 June-18 July) }\end{array}$ & 87 & $\begin{array}{c}75-94 \\
{[P<0.025]}\end{array}$ & $\begin{array}{l}0.88 \\
\text { (5 June-28 Aug.) }\end{array}$ & $4.5-6.9$ \\
\hline $\begin{array}{l}\text { Fall, } \\
1973\end{array}$ & 43 & $\begin{array}{l}71 \pm 50 \\
\text { (22 Oct. }-6 \text { Nov.) }\end{array}$ & 129 & $\begin{array}{l}124-138 \\
{[P<0.005]}\end{array}$ & $\begin{array}{l}0.92 \\
\text { (5 June-15 Dec.) }\end{array}$ & $5.7-10.1$ \\
\hline $\begin{array}{l}\text { Spring- } \\
\text { Summer, } \\
1974\end{array}$ & 36 & $\begin{array}{c}48 \pm 21 \\
\text { (26 June- } 3 \text { July) }\end{array}$ & 38 & $\begin{array}{c}35-40 \\
{[P<0.25]}\end{array}$ & $\begin{array}{l}0.22 \\
(28 \text { May-21 Aug.) }\end{array}$ & $3.0-3.7$ \\
\hline $\begin{array}{l}\text { Fall, } \\
1974\end{array}$ & 56 & $\begin{array}{c}86.1 \pm 30.2 \\
\text { (15 Oct. }-11 \text { Nov.) }\end{array}$ & 98 & $\begin{array}{c}95-101 \\
{[P<0.005]}\end{array}$ & $\begin{array}{l}0.60 \\
(28 \mathrm{May}-9 \text { Dec.) }\end{array}$ & $6.7-7.7$ \\
\hline \multicolumn{7}{|c|}{ B. Lorne study area (7.8 ha) } \\
\hline $\begin{array}{l}\text { Summer, } \\
1974\end{array}$ & 43 & $\begin{array}{l}48 \pm 4 \\
\text { (17 June-3 July) }\end{array}$ & & $\begin{array}{l}57-63 \\
{[P<0.005]}\end{array}$ & $\begin{array}{l}0.81 \\
\text { (2 June-21 Aug.) }\end{array}$ & $6.2-7.7$ \\
\hline $\begin{array}{l}\text { Fall, } \\
1974\end{array}$ & 56 & $\begin{array}{l}72 \pm 15.9 \\
\text { (21 Oct. }-6 \text { Nov.) }\end{array}$ & 108 & $\begin{array}{l}103-114 \\
{[P<0.005]}\end{array}$ & $\begin{array}{l}0.87 \\
\text { (2 June-19 Dec.) }\end{array}$ & $9.1-13.8$ \\
\hline
\end{tabular}

from as low as 3.7 flying squirrels/ha at Ashland in 1974 to as high as 7.4 flying squirrels/ha at Lorne (Table 4). Major expansion of the population was found to occur in late summer and early fall in most years. This expansion was most pronounced in 1974 at Ashland, when the fall population increased to a size approximately 1.8 to 2.5 times as great as that of the preceding summer. An increase of similar proportions occurred in the same year at the Lorne study area (Table 4). 


\section{DISCUSSION}

The peak of reproduction in Virginia occurred one month earlier in spring than reported by $\mathrm{Muul}$ (1969) for flying squirrels in Massachusetts and Michigan, or by S oll ber g e r (1943) for Ohio and Pennsylvania. However, the results are similar to those of $\mathrm{Goertz}$ et al. (1975) for northern Louisiana.

J ord a n (1948) and M a d d e n (1974) reported that standing fresh water was not a necessary component of flying squirrel habitat. $\mathrm{M} \mathrm{u} \mathrm{u} \mathrm{l}$ (1968), however, noted that nearly all nests were less than $100 \mathrm{~m}$ from water. The Virginia populations were clearly influenced by nearness to available ground water for their shelter sites, in agreement with Muul's findings.

Foraging ranges of adult males were significantly larger than those of adult females or juveniles, in contrast to M a d d e n's (1974) observations for Long Island, New York. Furthermore, no defense of territory by females against other females as reported by Madden for Long Island squirrels was ever observed at Ashland.

The data for population regulation indicates a range of densities throughout the year, correlated with peaks of reproduction and periods of high attrition. The assumptions of the Petersen index may be met most readily during brief, nonreproductive periods of the year. Mortality corrections were available also (Fig. 5). Horizontal population exchanges were minimized by the relatively isolated nature of the habitats studied. Consequently, the Petersen index estimates may approximate the natural population numbers, though with relatively large margins of error. Regression analysis of recapture frequency was used as an alternative to the Petersen index calculations for estimating flying squirrel abundance. This method was used by Edwards \& E ber$\mathrm{h}$ a r d t (1967) to estimate a known experimental cottontail rabbit population; with the exception of the Lincoln index, other methods tended to over or underestimate the number of individuals present. $\mathrm{Nix}$ on et al. (1967) working with two species of tree squirrels, also found that linear regression estimates closely approximated those obtained with the Lincoln index, whereas other methods produced poor fits and much lower values. The assumptions of the regression method are similar to those for the Petersen index, as described previously. In addition, the method assumes consistency of behavior by the animals with respect to the traps, an untested assumption. However, the high $R^{2}$ values and narrow confidence limits suggest a close fit between the regression estimates and the data (except for the spring-summer period, 1974, at 
Ashland), consistent with the hypothesis of relatively constant trap susceptibility.

The reliability of the population estimates is also influenced by the extent to which the sampling methods are capturing all classes in the population, e.g., new animals, recaptures, juveniles, adults, ... etc. However, comparison of the proportion of adults vs. juveniles at the two study areas did not reveal substantial differences (e.g., adults constituted $70.3 \%$ of the sample at Ashland, $76.2 \%$ at Lorne). Similar observations were noted in comparing males vs. females. No discernable bias was found which excluded any class of the population, and comparison of the estimates obtained at the two study areas as well as with the two sampling methods appears to be justified.

Census values were also determined for the different populations in each period to provide a comparison between the number of individuals known present and the numbers in each estimate. With one exception (spring-summer, 1973), census values were lower than the estimated total population.

Other workers reported flying squirrel densities ranging from 2.5 to 12.4/ha (B urt, 1940; S oll ber g e r, 1943; J or d a n, 1948, 1956; M u u 1, 1968; M a d d e n, 1974). However, their figures represent minimum densities in terms of the observed number of individuals per unit area rather than population estimates. Moreover, B ur t's \& J o r d a n's (1948) studies were done in mid-summer, before the second litters of the year. S o 11 berger's (1943) values of 4.6 and 12.4 animals/ha at two different localities were based on removal trapping. He recognized the inaccuracy of his estimates, noting that the area was not trapped to extinction. Census figures for flying squirrels at the two Virginia study areas are comparable to those reported by other workers in the eastern U.S. However, the actual numbers present are probably much greater, as suggested by the population estimates.

This study demonstrated that Glaucomys volans can attain relatively high densities in favorable habitat, with cyclical expansion and contraction of the population each year.

Acknowledgements: We are indebted to Dr. P. DeCoursey, Belle W. Baruch Institute, University of South Carolina, Columbia, South Carolina, for assistance with the preparation of the manuscript. We are also indebted to Dr. Ilar Muul, Environmental Quality Division, U.S. Army, Fort Detrick, Frederick, MD for assistance in selection of flying squirrel habitat, design of suitable shelters, and critical review of themanuscript. We also wish to thank Mr. Herb Dorsey, Management Systems, Bureau of Biologics, FDA, USPHS, for computer services involved in the numerous computations and statistical analyses used in this study, and to Dr. S. Rastogi, Bureau of Biologics, FDA, USPHS, for his assistance with regression analysis of the flying squirrel recapture data. Finally, we thank Mr. Douglas Cerretani, Mr. Gary Enlow, and Mr. Terry Musser for their assistance in trapping animals, and Ms. Zippora Katz for translating the summary into Polish. 


\section{REFERENCES}

1. Bozeman F. B., Masiello A. A., Williams M. S. \& Elisberg B. L., 1975: Epidemic Typhus rickettsiae isolated from flying squirrels. Nature, 255 (5509): $545-547$.

2. Burt W. H., 1940: Territorial behavior and populations of some small mammals in southern Michigan. Misc. Publ. Mus. Zool. Univ. Michigan, 45: 1-58.

3. Davis D. E., 1963: Estimating the numbers of game populations. [In: «Wildlife Investigational Techniques $\alpha$. Ed.: Mosby H. W.]. The Wildlife Society, 2nd ed.: 89-118. Washington, D. C.

4. De Coursey P. J., 1960: Phase control of activity in a rodent. Cold Spring Harbor Symp. Quant. Biol., 25: 49-55.

5. DeCoursey P. J., 1961: Effect of light on the circadian activity rhythm of the flying squirrel, Glaucomys volans. Z. Vergl. Physiol., 44: 331-354.

6. DeCoursey P. J., 1972: LD ratios and the entrainment of circadian activity in a nocturnal and a diurnal rodent. J. comp. Physiol., 78: 221-235.

7. DeCoursey P. J., 1973: Free running rhythms and patterns of circadian entrainment in three species of diurnal rodents. J. interdiscpl. Cycle Res., 4: 67-77.

8. Edwards W. R. \& E berhardt L., 1967: Estimating cottontail abundance from live trapping data. J. Wildl. Manage., 31, 1: 87-95.

9. Goertz J. W., Dawson R. M. \& Mowbray, E. E., 1975: Response to nest boxes and reproduction by Glaucomys volans in northern Louisiana. J. Mamm., 56, 4: 933-939.

10. Jordan J. S., 1948: A midsummer study of the southern flying squirrel. J. Mamm., 29: $44-48$.

11. J orda n J. S., 1956: Notes on population of eastern flying squirrels. J. Mamm., 37: $294-295$.

12. Ma dden J. R., 1974: Female territoriality in a Suffolk county, Long Island, population of Glaucomys volans. J. Mamm., 55, 3: 647-652.

13. Madden-Gia calone J. R. 1976: Behavioural ecology of the southern flying squirrel Glaucomys volans on Long Island, N.Y. Ph.D. Thesis, City University of New York. $110 \mathrm{pp}$.

14. Moore J. C. 1961: Geographic variation in some reproductive characteristics of diurnal squirrels. Bull. Am. Mus. Nat. Hist., 122, 1: 1-32.

15. M u u l I. 1968: Behavior and physiological influences on the distribution of the flying squirrel, Glaucomys volans. Misc. Publ. Mus. Zool., Univ. Michigan, 134: $1-66$.

16. Muul I., 1969: Photoperiod and reproduction in flying squirrels, Glaucomys volans. J. Mamm., 50, 3: 542-549.

17. Mu u 1 I., 1970: Intra- and inter-familial behavior of Glaucomys volans (Rodentra) following parturition. An. Behaviour, 18: 20-25.

18. Mu u l I., 1974: Geographic variation in the nesting habits of Glaucomys volans. J. Mamm., 55, 4: 840-844.

19. Nix on C. M., Edwards W. R. \& E berhard t L., 1967: Estimating squirrel abundance from live trapping data. J. Wildl. Manage., 31, 1: 96-101.

20. Riley V. 1960: Adaptation of the orbital bleeding technique to rapid serial blood studies. Proc. Soc. exp. Biol. Med., 104: 751.

21. Sollberger D. E., 1943: Notes on the breeding habits of the eastern flying squirrel (Glaucomys volans). Ibid. 24: 163-173. 
22. Sonenshine D. E., Cerretani D. G., Enlow G. \& Elisberg B. L., 1973: Improved methods for capturing wild flying squirrels. J. Wildl. Manage., 37, 4: $588-590$.

23. Stormer F. A. \& Sloan N., 1976: Evidence of the range extension of the southern flying squirrel in the upper peninsula of Michigan. The Jack-Pine Warbler, 54: 176.

24. Weigl P. D., 1974: Study of the northern flying squirrel Glaucomys sabrinus by temperature telemetry. Am. Midland Nat., 92, 2: 482-486.

Accepted, April 5, 1979

Daniel E. SONENSHINE, David M. LAUER, Thomas C. WALKER i Bennett L ELISBERG

\title{
EKOLOGIA GLAUCOMYS VOLANS W WIRGINII
}

\author{
Streszczenie
}

Assapan Glaucomys volans ( $\mathrm{L}$ inna e us, 1758) reaguje pozytywnie na sztuczne schrony i pułapki umieszczone na drzewach. Możliwe, że powodem tego jest ograniczona dostępność schronień naturalnych. Przedstawiono dowody, że zwierzątka używają system schronień przy czym różne z nich służą różnym celom (gniazdowanie, defekacja, gromadzenie pokarmu). Zimą gniazda zbudowane były wyłącznie z kory Juniperus virginiana $L$. a podczas lata z różnych materiałów.

Assapany wykazywały istotną tendencję do zasiedlania kryjówek w pobliżu wody (Tabela 2). Rodzaj terenu, (górzysty lub równinny) czy też odległość od wody nie miały wpływu na zasięg penetracji terenu w celu zdobywania pokarmu. Zasięg ten obejmował $126.8 \mathrm{~m} \pm 14.8$ S.E., i był znacznie większy u dorosłych samców niż u nieaktywnych samic lub osobników młodocianych (Ryc. 3).

Aktywność seksualna ma charakter sezonowy (Tabela 3). Porody ograniczone były do 2 wyraźnie określonych okresów: wiosną i na przełomie lata i jesieni. Zmiany ciężaru ciała specjalnie u samic były związane $z$ cyklem płciowym (Ryc. 4). Większość samic $(94.2 \%)$ zachodziło $\mathrm{w}$ ciążę $\mathrm{w}$ ciągu 6-8 miesięcy po urodzeniu. Najstarsza samica zdolna do rozrodu była w wieku 3 lat i 8 miesięcy. Porody miały miejsce na początku wiosny (marzec, kwiecień) i pod koniec lata lub z początkiem jesieni. Mlodociane assapany zjawiły się w pułapkach około 60 do 80 dni po urodzeniu.

Ubywanie assapanów z populacji prawie wyłącznie było spowodowane śmiertelnością. Z kohorty wiosennej $50 \%$ osobników przeżywało $5 \frac{1}{2} 2$ miesiąca a $67 \%$ 7 miesięcy. Analogicznie w kohorcie jesiennej wartości te wynosiły 5 i 8 miesięcy (Ryc. 5).

Zagęszczenie liczone wg indeksu Petersena i metodą analizy regresji zmieniały się zależnie od sezonu od 4.5 do 10.1 assapanów/ha w jednej miejscowości i 'od 6.2 do 13.8 w drugiej miejscowości (Tabela 4). 